\title{
Among sheeples and antivaxxers: Social media responses to COVID-19 vaccine news posted by Canadian news organizations, and recommendations to counter vaccine hesitancy
}

\author{
Lisa Tang ${ }^{1 *}$, Sabrina Douglas ${ }^{1}$, Amar Laila ${ }^{1}$
}

\begin{abstract}
Background: To create a successful public health initiative that counters vaccine hesitancy and promotes vaccine acceptance, it is essential to gain a strong understanding of the beliefs, attitudes and subjective risk perceptions of the population.

Methods: A qualitative analysis of coronavirus disease 2019 (COVID-19) vaccine discourse from 3,731 social media posts on the Twitter and Facebook accounts of six Canadian news organizations was used to identify the perceptions, attitudes, beliefs and intentions of Canadian news organizations' social media commenters toward taking a COVID-19 vaccine.
\end{abstract}

Results: Four main themes were identified: 1) COVID-19 vaccine safety and efficacy concerns; 2) conspiracy theories stemming from mistrust in government and other organizations; 3 ) a COVID-19 vaccine is unnecessary because the virus is not dangerous; and 4) trust in COVID-19 vaccines as a safe solution. Based on themes and subthemes, several key communication recommendations were developed for promotion of COVID-19 vaccine acceptance, including infographics championed by Public Health that highlight the benefits of the vaccine for those who have received it, public education about the contents and safety of the vaccine and eliciting an emotional connection through personal stories of those impacted by COVID-19.

Conclusion: Specific considerations, such as leveraging the public's trust in healthcare professionals to act as a liaison between Public Health and the Canadian public to communicate the benefits of the vaccine against COVID-19 and its variants, may help reduce COVID-19 vaccine hesitancy.
This work is licensed under a Creative Commons Attribution 4.0 Internationa License.

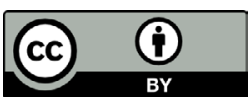

Affiliation

1 Department of Family Relations and Applied Nutrition, University of Guelph, Guelph, ON

*Correspondence:

lisa.tang@uoguelph.ca

Suggested citation: Tang L, Douglas S, Laila A. Among sheeples and antivaxxers: Social media responses to COVID-19 vaccine news posted by Canadian news organizations, and recommendations to counter vaccine hesitancy. Can Commun Dis Rep 2021;47(12):524-33. https://doi.org/10.14745/ccdr.v47i12a03

Keywords: vaccine hesitancy, social media, health communication, COVID-19, vaccines

\section{Introduction}

Severe acute respiratory syndrome coronavirus-2 (SARS-CoV-2) is an infectious respiratory pathogen responsible for coronavirus disease 2019 (COVID-19) (1). To slow the spread of COVID-19, many regions within Canada instituted indoor mask use and physical distancing. On March 23, 2020, Prime Minister Justin Trudeau urged Canadians to "go home and stay home" and adhere to physical distancing recommendations. Following increasing evidence of asymptomatic spread, on April 6, 2020, Canada's Chief Public Health Officer recommended Canadians wear non-medical masks (2). Even with these mitigation measures, as of September 2021 there were more than
27,000 deaths in Canada—and over 4.6 million deaths worldwide $(3,4)$. Given that vaccines are the most successful and important public health intervention to prevent spread of infectious disease (5), it has become well accepted that a COVID-19 vaccine is the best way to develop both personal and population-level immunity $(6,7)$. In September 2020, the expedited process of approving COVID-19 vaccines was authorized in Canada (8), which allowed for approval of PfizerBioNTech, Moderna, AstraZeneca and Janssen vaccines between the end of 2020 and early 2021 (9). 
Research has shown that public confidence in vaccines has remained low in recent years and continues to be a dynamic and complex issue (10-12). Lack of vaccine confidence has resulted in vaccine hesitancy, identified by the World Health Organization as one of the top 10 threats to global health (13). Vaccine hesitancy is defined as refusal or delay in acceptance of an available vaccine and is context specific, meaning that an individual may refuse some vaccines and accept others (14). Digital communication technology, such as social media (SM), has been found to propagate the spread of vaccine-related misinformation (15) that contributes to vaccine hesitancy (16).

Opportunities exist to leverage SM use for public health initiatives that counter vaccine misinformation and increase vaccination rates $(16,17)$. This is an important consideration as the Canadian Community Health Survey shows $75 \%$ of Canadians aged 12 years and older would be somewhat or very likely to get the COVID-19 vaccine (18). Results from Angus Reid Institute showed that $48 \%$ of Canadians said that they would receive a COVID-19 vaccine when available, $38 \%$ would eventually but not immediately, $14 \%$ would not and $7 \%$ were unsure (19). These attitudes towards COVID-19 vaccinations are important to consider given a large proportion of the population needs to be vaccinated to achieve herd immunity (20).

To create successful public health initiatives that counter vaccine hesitancy and promote vaccine acceptance, it is necessary to gain an understanding of the beliefs, attitudes and subjective risk perceptions of the population (21). A recent study examining COVID-19 vaccine intention found that perceived benefits and barriers played a role in intention to receive the COVID-19 vaccine (22). Neubaum and Krämern stated that SM may serve as "a window to the public", providing insight into public perception and opinion. Research has shown that SM users may feel empowered to share their thoughts and opinions when they see posts espousing similar beliefs $(23,24)$ and when they can do so anonymously (25). These online comments act as an accurate and reliable source of information on public attitudes and perceptions that surface during a health crisis (26). For example, a recent study used English-language Twitter posts to examine public perceptions of COVID-19 social distancing measures (27) and found their results reflected the attitudes and opinions of a large United States public opinion poll taken during the same timeframe $(28,29)$. Taken together, SM could be used to gain an understanding of perspectives of the Canadian population towards public health issues, including perceptions, beliefs, attitudes and intentions toward receiving a COVID-19 vaccine.

In recent months, perceptions and attitudes toward taking a COVID-19 vaccine (30-32) have been investigated, and a growing body of research has focused on those perceptions and attitudes expressed on SM (33-36). To better inform public health recommendations to counter vaccine hesitancy in Canada, further research that examines SM discourse on Twitter and Facebook in response to Canadian news organizations'
COVID-19 vaccine reporting may help provide a more comprehensive understanding of the attitudes, beliefs and intentions toward taking a COVID-19 vaccine among Canadians.

\section{Methods}

\section{Data collection}

Six popular Canadian national news organizations were selected; specifically, Global News, Canadian Broadcasting Corporation (CBC), Canadian Television Network (CTV), The Globe and Mail, Maclean's and The National Post to identify the perceptions, attitudes, beliefs and intentions of Canadian news organizations' SM commenters toward taking a COVID-19 vaccine. These are the predominant national news content providers in Canada that report the news through television broadcast (Global News, CBC, CTV) or print (The Globe and Mail, Maclean's, The National Post), as well as online. Compared with a quantitative analysis, which provides information on vaccine of hesitancy patterns among populations, a qualitative approach offers a deeper analysis of the socio-cultural aspects of vaccine hesitancy (37). Thus, a qualitative approach was selected to allow for an in-depth exploration into the nuances and complexities of vaccine hesitancy among Canadians.

Social media posts from the Twitter and Facebook accounts of the six Canadian news organizations listed above were monitored for when a COVID-19 vaccine-related article was shared on their Twitter and Facebook account. Twitter and Facebook were chosen because comments on these platforms have been used to answer vaccine hesitancy research questions in previous studies $(33,38,39)$ and both platforms allow news organizations to link back to articles on their website. All data were gathered between July and September 2020, and only English posts were collected for analysis. Each SM post included a link to their respective news article and often included a comment inviting SM engagement. These news organizations were selected because they are nationally representative organizations with credible reporting practices and represent a range in political leanings. All commenters are users of SM with accounts on Twitter and/or Facebook. Authors looked for news articles that included information on development or procurement of COVID-19 vaccines or reported on vaccination survey results. Seven days after the COVID-19 related news article was shared on the organizations' SM account, all posted comments were collected. A seven-day timeframe was sufficient to collect SM comments made on that article, as few comments were posted after this time.

A total of six articles (one article per new organization posted on both Twitter and Facebook) and 4,095 comments were collected for analysis. The data were then scanned for spam, which was defined as insults toward other commenters, comments that were not on the topic of the COVID-19 vaccine, comments that were not legible (e.g. used only characters) and images (e.g. 
GIFS). A total of 364 posts that included spam and irrelevant comments were deleted and images that contained text, if related to COVID-19, were transcribed verbatim. Once data cleaning was complete, a total of 3,731 posts remained for analysis. The number of posts per news organization and links to each original article are shown in Table 1.

\section{Table 1: Total number of combined Twitter and Facebook posts for each news organization used in analysis and links to each news organizations' original COVID-19 vaccine related article posted on their respective social media accounts}

\begin{tabular}{|l|r|l|}
\multicolumn{1}{c}{$\begin{array}{c}\text { News } \\
\text { organization }\end{array}$} & $\begin{array}{c}\text { Number of } \\
\text { posts }\end{array}$ & \multicolumn{1}{|c|}{ Link to original article } \\
\hline National Post & 308 & $\begin{array}{l}\text { https://nationalpost.com/health/which- } \\
\text { canadians-get-the-covid-19-vaccine- } \\
\text { first-experts-are-struggling-to-decide }\end{array}$ \\
\hline Maclean's & 642 & $\begin{array}{l}\text { https://www.macleans.ca/society/ } \\
\text { health/how-anti-vaxxers-could-disrupt- } \\
\text { the-cure-for-the-covid-19-pandemic/ }\end{array}$ \\
\hline $\begin{array}{l}\text { The Globe } \\
\text { and Mail }\end{array}$ & 70 & $\begin{array}{l}\text { https://www.theglobeandmail.com/ } \\
\text { canada/article-moderna-inc-says- } \\
\text { its-covid-19-vaccine-shows-positive- } \\
\text { results-among/ }\end{array}$ \\
\hline Global News & 745 & $\begin{array}{l}\text { https://globalnews.ca/news/7251593/ } \\
\text { canada-pfizer-coronavirus-vaccine/ }\end{array}$ \\
\hline CBC & 498 & $\begin{array}{l}\text { https://www.cbc.ca/news/world/ } \\
\text { coronavirus-covid19-world- } \\
\text { sept4-1.5712020 }\end{array}$ \\
\hline CTV & 1,468 & $\begin{array}{l}\text { https://www.ctvnews.ca/health/ } \\
\text { coronavirus/feds-sign-deals-with- } \\
\text { novavax-and-johnson-johnson- } \\
\text { to-secure-millions-of-vaccine- } \\
\text { doses-1.5085911 }\end{array}$ \\
\hline
\end{tabular}

Abbreviations: CBC, Canadian Broadcasting Corporation; COVID-19, coronavirus disease 2019, CTV, Canadian Television Network

This research study relied exclusively on publicly available data with some sources as anonymous or unidentifiable; therefore, ethical approval was not required. This is consistent with similar Canadian-based research using publicly available SM content (33).

\section{Analysis}

Original posts from each news organizations' Twitter and Facebook account, along with accompanying comments, were imported into NVivo-12 (QSR International, 2019). Using Clarke and Braun (40) as a guide, each of this study's researchers conducted thematic analysis to identify themes as the unit of analysis. Analysis involved each researcher independently coding each comment and reply over a 10-week period. Researchers met bi-weekly to examine and discuss differences in the codes, which became the building blocks of the themes (40). Based on previous vaccine hesitancy literature, perceptions, attitudes, beliefs and intentions were used as sensitizing concepts to approach qualitative analysis. Sensitizing concepts refer to general ideas that act as starting points for researchers approaching a qualitative research question (41). Using these sensitizing concepts as guide for analysis, the authors then used inductive analysis to allow themes and patterns to emerge from the data (41). All three researchers noticed similar themes among the data, and once coding was complete, all researchers met to finalize the list of agreed themes and subthemes.

\section{Results}

Four themes emerged from comments gathered in response to news organizations' SM posts. For each theme, subthemes were also identified. Most SM comments and replies expressed negative attitudes and opinions toward the COVID-19 vaccine, while some expressed positive beliefs and attitudes. Each theme is described in the following pages, where illustrative quotes were used to contextualize themes. A summary of themes with supplementary quotes can be found in Table 2 .

\section{Theme 1: COVID-19 vaccine safety and efficacy concerns}

Theme 1 captured concerns about perceived factors that may influence the safety and efficacy of the vaccine including political pressures, development speed and testing, ingredients and potential immune-escaping variants.

Political pressures influencing vaccine production: Concerns were expressed around the perceived influence of political pressures rushing vaccine production. For example, one commenter noted "Would I get the Russian vaccine or Trump's vaccine to win an election[?] .. not a chance." - CTV, Twitter. Another commenter, referring to the influence of politicians wrote, "Medical experts are dictated what to do by politicians. Trust them at your peril" - Globe and Mail, Facebook.

Others first to prove safety: A common concern referred to safety of vaccine and the belief that they lacked adequate testing. Many commenters remarked that politicians should receive the vaccine first to prove its safety: "I want the whole House of Commons, the Senate, the Governor-General and a special vaccine for the Prime Minister! Then we wait a month and see what happens!" - CTV, Facebook. Another wrote, "I will let the masses be the control group and see what happens. It may be good or not. Time and trial will tell" - CBC, Facebook.

Rushed vaccine: Many commenters expressed concern about the short timeframe for COVID-19 vaccine development. One commenter who characterized themselves as not being an "anti-vaxxer", a word that describes someone who is opposed to vaccines, noted, "There will be a lot of people like me who are not anti-vaxxers but will refuse this until a reasonable amount of time for proper testing and data goes by." - National Post, Facebook. 
Table 2: Supplementary quotes from social media commenters in response to Canadian news organizations' COVID-19 vaccine related Twitter and Facebook posts organized by theme and subtheme

\begin{tabular}{|c|c|c|}
\hline Theme & Subtheme & Quote \\
\hline \multirow{5}{*}{$\begin{array}{l}\text { COVID-19 } \\
\text { vaccine safety } \\
\text { and efficacy } \\
\text { concerns }\end{array}$} & $\begin{array}{l}\text { Political pressures } \\
\text { influencing } \\
\text { vaccine } \\
\text { production }\end{array}$ & $\begin{array}{l}\text { "These scientists are under a tremendous amount of pressure for governments to push though and get a } \\
\text { vaccine up and running and that's how we end up with oppsys" - CTV, Facebook } \\
\text { "Would you take a vaccine that did not undergo full trials? DJT [Donald J Trump] is proposing forgoing phase } 3 \\
\text { trials in order to rush a vaccine to production" - CBC, Twitter }\end{array}$ \\
\hline & $\begin{array}{l}\text { Others first to } \\
\text { prove safety }\end{array}$ & $\begin{array}{l}\text { "I'll wait for all the heroes to go first, if they survive maybe" - CTV, Twitter } \\
\text { "Nope. Not until I see what happens to all the eager beavers. I'm no guinea pig" - CTV, Twitter } \\
\text { "The yes voters can line up to be guinea pigs while the intelligent people wait and see what happens." - Global } \\
\text { News, Twitter } \\
\text { "I think all our lovely politicians should be the first to get it and we can all wait } 6 \text { months to see how that turns } \\
\text { out." - CTV, Facebook }\end{array}$ \\
\hline & Rushed vaccine & $\begin{array}{l}\text { "I wont be a Guinea pig. I'll wait 5-10 years for a long term study to be peer reviewed and make sure the side } \\
\text { effects of the vaccine arent worse than the effort it takes to avoid covid." - CBC, Facebook } \\
\text { "Anybody dumb enough to get injected by a rushed and undertested vaccine deserves every side effect from } \\
\text { it." - CTV, Facebook } \\
\text { "Nope... and I am not anti vaxx.....I am anti being a guinea pig for a rushed vaccine that hasn't been properly } \\
\text { tested" - CTV, Facebook } \\
\text { "I am not against vaccines but I will not be getting this. It's just too fast and not tested enough for me to want } \\
\text { to take this." - Maclean's, Facebook } \\
\text { "You do know it takes roughly } 10 \text { years to develop and properly test a vaccine right? Go ahead and trust } \\
\text { something developed in } 4 \text { months with zero long term effects results but if you value yourself you'd wait until } \\
\text { you had irrefutable evidence that this vaccine is } 100 \% \text { safe with only a SMALL chance of complications taking } \\
\text { place like every other rigorously tested and proven to be safe vaccine." - National Post, Facebook }\end{array}$ \\
\hline & $\begin{array}{l}\text { Ingredient } \\
\text { concern }\end{array}$ & $\begin{array}{l}\text { "go ahead and have and have mine too but don't judge others that have no desire to put unknown chemicals in } \\
\text { their body" - CTV, Facebook } \\
\text { "...check what is in vaccines and what they really do and they don't want chemicals like formaldehyde, mercury } \\
\text { and aluminum in their bodies" - Maclean's, Facebook } \\
\text { "Read the insert and see what is in it. Fetal DNA. Yes, aborted fetus cells. Toxic chemicals beyond } \\
\text { comprehension. You demand a mask for your health and then BLINDLY inject these toxins directly into your } \\
\text { bloodstream. RESEARCH what's in them!" - Global News, Twitter }\end{array}$ \\
\hline & $\begin{array}{l}\text { Vaccine versus } \\
\text { variants }\end{array}$ & $\begin{array}{l}\text { "We don't yet know, or at least aren't told the mutation rate of Covid ... vaccination may be a frequent } \\
\text { undertaking and possibly with no real effect." - National Post, Facebook } \\
\text { "covid is already mutating so good luck with that" - CBC, Facebook } \\
\text { "Think of how many times the virus will have morphed by the time they actually get the vaccine out..." - CBC, } \\
\text { Facebook }\end{array}$ \\
\hline \multirow{4}{*}{$\begin{array}{l}\text { Conspiracy } \\
\text { theories } \\
\text { stemming } \\
\text { from } \\
\text { mistrust in } \\
\text { government } \\
\text { and other } \\
\text { organizations }\end{array}$} & $\begin{array}{l}\text { General mistrust } \\
\text { in government }\end{array}$ & $\begin{array}{l}\text { "I don't trust our government anymore and won't be used as a guinea pig." - Global News, Twitter } \\
\text { "Who wants to take a shot in the arm, from a gov. that has had } 3 \text { ethics investigations, is so very far from } \\
\text { anything resembling "transparency" it should really be criminal. JT [Justin Trudeau] - fancy socks mr. word salad } \\
\text { has been sticking it up our Cdn. butts long enough, no don't touch my arm. Clearly you are Not to be trusted." } \\
\text { - CTV, Facebook } \\
\text { "... Just because the government says it's okay and pushes thru the creation and testing does not make me feel } \\
\text { confident about it." - Global News, Facebook } \\
\text { "0\% trust in the Canadian Healthcare system to provide a safe version of CV19 vaccination." - Global News, } \\
\text { Twitter } \\
\text { "Scientists can be bought just like politicians. Stop being naive thinking the government wants what's best for } \\
\text { us". - CTV, Facebook }\end{array}$ \\
\hline & $\begin{array}{l}\text { COVID-19 } \\
\text { vaccine will alter } \\
\text { your DNA }\end{array}$ & $\begin{array}{l}\text { "Do you realize that the new mRNA vaccine which BigPharma is touting as the savior from COVID is in fact } \\
\text { altering your DNA? No wonder they put Gates in the forefront to sell it. They're labeling it as The "Software of } \\
\text { Life." - Global News, Twitter } \\
\text { "Enjoy having your DNA altered for the rest of your life and your children's life." - Global News, Twitter } \\
\text { "Why would I take it knowing it was DNA chipped. Meaning changing your genomes and DNA ... Should have } \\
\text { been asking why are they are rushing to inject the population with it." - CTV, Facebook }\end{array}$ \\
\hline & & $\begin{array}{l}\text { "I don't want to be microchipped from Bill Gates, it's a mind control device which can simply make you walk off } \\
\text { the edge of the flat Earth Face with hand over mouth." - Global News, Twitter }\end{array}$ \\
\hline & $\begin{array}{l}\text { Microchips and } \\
\text { nanotechnology }\end{array}$ & $\begin{array}{l}\text { "Those of us with a strong immune system will survive just fine without Gatesfromhell vaccine that he has } \\
\text { admitted will kill over } 700000 \text { people. You go get yourself microchipped like a cow." - Maclean's, Facebook } \\
\text { "There's a huge difference between a chip in a phone or electronic and one in your body! At least you can leave } \\
\text { your phone home." - CTV, Facebook }\end{array}$ \\
\hline
\end{tabular}


Table 2: Supplementary quotes from social media commenters in response to Canadian news organizations' COVID-19 vaccine related Twitter and Facebook posts organized by theme and subtheme (continued)

\begin{tabular}{|c|c|c|}
\hline Theme & Subtheme & Quote \\
\hline \multirow{3}{*}{$\begin{array}{l}\text { COVID-19 } \\
\text { vaccine is } \\
\text { unnecessary } \\
\text { because the } \\
\text { virus is not } \\
\text { dangerous }\end{array}$} & $\begin{array}{l}\text { It is just "fear } \\
\text { mongering" }\end{array}$ & $\begin{array}{l}\text { "I'm sure we could go back to pre-plandemic life if the media just quit the fear mongering" - CTV, Facebook } \\
\text { "your fear propaganda is a farce. your mask mandates are a farce. your inflated statistics are a farce." - CTV, } \\
\text { Facebook } \\
\text { "Just some more fear mongering by our ridiculous government have a great day." - CTV, Facebook }\end{array}$ \\
\hline & $\begin{array}{l}\text { COVID-19 is not } \\
\text { that serious }\end{array}$ & $\begin{array}{l}\text { "You had better chance dying of cancer or car fatalities any other health reason on a daily basis then getting } \\
\text { infected with COVID or dying from it." - CTV, Facebook } \\
\text { "Is a vaccine really required for a disease so deadly one has to get tested to see if they have it" - CTV, Facebook } \\
\text { "my wife and I both had it (we are both immunodeficient) No hospital stay the cough lasted about } 3 \text { weeks and } \\
\text { we have } 0 \text { long term affects." - CTV, Facebook } \\
\text { "A vaccine for a virus with a } 0.03 \% \text { mortality rate? I'll pass thanks!" - The Globe and Mail, Facebook }\end{array}$ \\
\hline & $\begin{array}{l}\text { Strong immune } \\
\text { systems and a } \\
\text { healthy lifestyle is } \\
\text { sufficient to beat } \\
\text { COVID-19 }\end{array}$ & $\begin{array}{l}\text { "I'm not immune compromised, I'm not a senior, I'm healthy, and every flu I've had, my bodies own defenses } \\
\text { have overcome it in the normal anticipated time of infection." - Global News, Facebook } \\
\text { "just eat, sleep and exercise and you will be fine. if everyone did that then } 80 \text { percent of the healthcare system } \\
\text { wouldn't be needed." - Global News, Facebook } \\
\text { "I would like to be immune to it with my natural bodies antibodies." - Global News, Facebook } \\
\text { "Eating healthy: Non processed, non GMO, organic foods, exercise, get a good amount of sleep, take vitamins, } \\
\text { get lots of vitamin d from sun, the list goes and on and on of what you can do to stay healthy. I don't need } \\
\text { chemicals to keep me healthy. Let the body do its thing and if I catch a cold, flu or covid then i will deal with it." } \\
\text { - Global News, Facebook }\end{array}$ \\
\hline \multirow{3}{*}{$\begin{array}{l}\text { Trust in } \\
\text { COVID-19 } \\
\text { vaccines as a } \\
\text { safe solution }\end{array}$} & $\begin{array}{l}\text { Trust in science } \\
\text { and medical } \\
\text { professionals }\end{array}$ & $\begin{array}{l}\text { "I've seen the ingredients, and unlike some people, I don't misinterpret them. Some ingredients might look } \\
\text { sketchy to anyone who doesn't understand chemistry." - Global News, Twitter } \\
\text { "id say testing on over 50,000 people is good enough" - Global News, Facebook } \\
\text { "no one is going to be distributing an untested vaccine. It may not be possible to test for long-term protection, } \\
\text { but it will definitely be tested for both safety and effectiveness." - CTV, Facebook } \\
\text { "As I said, my risk management plan involves listening to my family doctor, and to my wife who is a retired } \\
\text { infection control nurse. Those two women have never led me astray. I wish you good luck with your alternate } \\
\text { plan." - Maclean's, Facebook } \\
\text { "The reason it can be made so fast is because it is a virus we are familiar with. Also not sure if you realize this } \\
\text { but research and technology has progressed" - CBC, Facebook }\end{array}$ \\
\hline & $\begin{array}{l}\text { Concern about } \\
\text { long term effects } \\
\text { of COVID-19 }\end{array}$ & $\begin{array}{l}\text { "The issue is not only the mortality of covid, but the seriousness of the illness and the long term effects. But } \\
\text { for now, you may not die from covid, but you may die waiting for help in an overcrowded hospital full of covid } \\
\text { patients." - Globe and Mail, Facebook } \\
\text { "almost everyone interviewed in media, old and young, who have had it are saying they're still not feeling } 100 \% \\
\text {... some have memory loss, loss of energy etc." - CTV, Facebook } \\
\text { "Healthy people can still suffer permanent damage and death" - Global News, Twitter }\end{array}$ \\
\hline & $\begin{array}{l}\text { Intent to get } \\
\text { the COVID-19 } \\
\text { vaccine to } \\
\text { protect others } \\
\text { and return to } \\
\text { "normal" }\end{array}$ & $\begin{array}{l}\text { "Thank you for one of the few voices of reason in a crowd of howling anti-vaxxers. As someone with loved ones } \\
\text { with health concerns, I will be first in line to get my shot." - CTV, Facebook } \\
\text { "Maybe if everyone got vaccinated, used masks, and social distance then maybe life would get back to normal } \\
10 \text { times faster than predicted." - CTV, Facebook }\end{array}$ \\
\hline
\end{tabular}

Abbreviations: CBC, Canadian Broadcasting Corporation; COVID-19, coronavirus disease 2019; CTV, Canadian Television Network

Ingredient concern: Safety concerns related to the ingredients used to develop the COVID-19 vaccine. "You go ahead fill your veins with fetus tissue and mercy and formaldehyde and then get back to ya and see how great you feel!" - Global News, Facebook.

Vaccine versus variants: Commenters were concerned about vaccine efficacy once the COVID-19 virus mutates. One commenter wrote, "There is the distinct possibility that covid mutates and renders any vaccine useless" - Maclean's, Facebook, while another noted, "Think of how many times the virus will have morphed by the time they actually get the vaccine out...". CBC, Facebook.

\section{Theme 2: Conspiracy theories stemming from mistrust in government and other organizations}

Theme 2 characterized the conspiracy theories, including microchips and changes to DNA, expressed on SM rooted in a general mistrust of government and organizations involved in COVID-19 vaccine development. 
General mistrust in government: All six news organizations' article posts on SM contained comments pointing toward mistrust of foreign and domestic government and health organizations. One commenter when speaking about the government wrote, "No one iota of trust. I am not a guinea pig for government vaccine tests" - Global News, Twitter.

The COVID-19 vaccine will alter DNA: Comments about the vaccine altering DNA were common on all news organizations' SM platforms: "Insane! Do these people have any idea what this vaccine entails?! It will literally alter your DNA. Forever." - Global News, Facebook. Another commenter wrote, "I don't need nor do I want anyone altering my DNA" - Global, News, Twitter.

Microchips and nanotechnology: Discourse focused on microchips and nanotechnology was common. One commenter wrote, "I dont wanna get chipped" - CTV, Facebook, while another responded, "Bill Gates can keep his nanobot juice, lol." Global News, Facebook.

\section{Theme 3: A COVID-19 vaccine is unnecessary because the virus is not dangerous}

Theme 3 captured the level of concern related to the perceived seriousness of becoming infected with COVID-19 expressed on SM. Commenters felt that severity was being overexaggerated and a healthy immune system was sufficient to overcome the virus.

It's just "fear mongering": Many commenters felt the virus is not as serious as the media was reporting. In response to a question posed by a news agency asking whether people will get the vaccine, one commenter responded, "Just some more fear mongering by our ridiculous government". - CTV, Facebook.

COVID-19 is not that serious: Many commenters noted that a COVID-19 vaccine was unnecessary because the virus was not dangerous. For example, "It's already hit my house, both my wife and I at very high risk, no hospital for either of us and yet here we are!!" - CTV, Facebook, while another commenter wrote, "I'm more likely to die walking down my stairs than die of Covid." Global News, Twitter.

Strong immune systems and a healthy lifestyle is sufficient to beat COVID-19: Commenters discussed how being in good health was sufficient to overcome the virus, "Maybe it's the world's way of weeding out the weak. Most have underlying conditions and we are in perfect health so covid is not a concern for us." - CBC, Facebook. Another commenter wrote, "eat healthy vitamins that's the best vaccine we can get it". - CTV, Facebook.

\section{Theme 4: Trust in COVID-19 vaccines as a safe solution}

A minority of commenters expressed confidence in COVID-19 vaccines to prevent infection. Those with confidence in the vaccine conveyed trust in science and their healthcare professional, expressed concerns about potential long-term COVID-19 effects and felt that the vaccine was necessary to return to normal.

Trust in science and medical professionals: Commenters expressed trust in the science behind the vaccines: "If health Canada approves a vaccine, I'll be in the first available line" - CTV, Twitter. Another commenter wrote, "Sign me up, Surprisingly I trust science and the medical safeguards in place. I know completely unheard of." - National Post, Facebook.

Other commenters expressed trust in medical professionals: "If my Dr. Recommends it I would." - Global News, Twitter. Another wrote, "I will follow my doctors advice as I dont have a spleen." - Global News, Twitter.

Concern about long-term effects of COVID-19: Several commenters noted concern about potential long-term effects of being infected with the COVID-19 virus. One commenter wrote, "the issue is not just those who have died but those who have survived, what they went through and the longer lasting effects..." - CTV, Facebook. Another wrote, "I'm more then willing to take it, the long-term effects from getting Covid are the driving force for me" - CTV, Facebook.

Intent to get the COVID-19 vaccine to protect others and return to "normal": Commenters expressed intention to get the COVID-19 vaccine so that they are able to return to their normal life, "Will be first in line so we can go back to normal" - CTV, Facebook. Another wrote, "As soon as it's available! Definitely plan on doing my part to protect the vulnerable" - Global News, Facebook.

In contrast, those expressing intention to receive the COVID-19 vaccine were met with ridicule. Comments such as "Yup...all the scared sheeple will be lining up dutifully and shaming anyone who resists" - CBC, Twitter, were common.

\section{Discussion}

The aim of this study was to examine SM discourse on Canadian news organizations' SM accounts in response to posted articles reporting on the COVID-19 vaccine. Comments on article posts were analyzed to identify perceptions, attitudes, beliefs, and intentions toward taking a COVID-19 vaccine. Our analysis identified four themes and a number of sub-themes. 
Comments expressing concern about safety and efficacy of a COVID-19 vaccine were common. This is consistent with previous research that examined reasons for vaccine hesitancy, with safety and efficacy concerns as the main driver for vaccine hesitancy $(42,43)$. The common concern about a "rushed" vaccine is not unique to COVID-19. Research examining responses to the $\mathrm{H} 1 \mathrm{~N} 1$ vaccine found that people were concerned about seemingly rushed vaccine development (44). These findings are consistent with our analysis and are troubling as research has found that COVID-19 vaccine acceptance is strongly related to perceived safety (45).

Commenters were concerned about ingredients in the COVID-19 vaccine. These findings are consistent with previous research by Björkman and Sanner (46) that examined the experiences and beliefs of taking the H1N1 vaccine in Sweden. This study determined that participants were concerned about putting "unknown substances" contained within the vaccine into their body (46). Taken together, it appears a lack of understanding regarding vaccine contents has been a consistent barrier to vaccine uptake.

Social media commenters were concerned about COVID-19 viral mutations rendering the vaccine ineffective against the virus. Research has shown that speed of vaccination can offset the harm of more easily transmissible variants (47). Thus, Public Health messaging that addresses concerns about COVID-19 viral variants and encourages uptake of the vaccine is needed.

Our analysis found that a reason for supporting a COVID-19 vaccine was concern about potential long-term effects of the virus. This is consistent with previous research that identified that perceptions of disease severity were associated with willingness to receive a COVID-19 vaccine $(43,48,49)$. One suggestion to increase vaccine uptake could be the sharing of local data through clear infographics to illustrate the success of the COVID-19 vaccine for those who been vaccinated. This may positively influence those who are hesitant on efficacy grounds, with messaging emphasis shifted toward the risk of developing long-haul COVID-19 symptoms. Additionally, it is clear from our results and previous research $(43,48,50)$ that healthcare providers are effective participants in vaccine communication, as several commenters mentioned that they would get the vaccine if it was recommended by their doctor.

\section{Limitations}

Study limitations should be considered when interpreting results. First, it is likely that readers who comment on vaccine-related posts have strong negative feelings toward the vaccine. Research has shown that anti-vaccine content on SM leads to more user engagement than pro-vaccine content (16). Second, we did not investigate each commenter to identify non-human accounts, specifically "bots". Bots are defined as automated accounts that can be designed to spread misinformation and anti-vaccination content (51). Yuan et al. found $1.45 \%$ of accounts participating in vaccine discourse on SM were bots (52). Third, only English posts were included in analysis and therefore not representative of the broader non-English speaking population. Although data were independently coded by each of the three researchers to reduce bias (53), we only used social media posts and therefore could not triangulate findings from multiple sources of information. Finally, we could not collect demographic information from commenters and therefore could not make conclusions about generalizability of results to the Canadian population. Future research in this area should consider multiple methods of data collection to test validity through analysis of information from several sources, examine SM discourse in languages other than English and on additional SM platforms.

\section{Future directions}

Results from this study can help inform Canadian Public Health COVID-19 vaccine messaging. Previous research has shown that Public Health communications can positively impact vaccine intention (22), and themes found in this study are consistent with previous research that aimed to identify effective vaccine messaging. Indeed, increasing public knowledge of COVID-19 disease severity and vaccine safety is imperative since these were primary concerns from commenters in this study and from participants in previous research $(42,49,54,55)$. Further, our results are consistent with published literature $(43,48,50)$ demonstrating healthcare providers can be an effective mode for reliable vaccine communications. Taken together, successful efforts can be made toward improving vaccine messaging on SM to reduce vaccine hesitancy.

A renewed public information drive is required to promote public urgency in vaccination as an important tool in fighting COVID-19 and its variants. Our analysis points to key recommendations that may help increase vaccine uptake and decrease hesitancy. This includes the following: 1) Public Health messaging focused on increasing the public's understanding of COVID-19 vaccine contents; 2 ) leveraging the public's trust in healthcare professionals to act as a liaison between Public Health and the Canadian public to communicate benefits of the vaccine against COVID-19 and its variants; 3) clear infographics championed by Public Health that highlight benefits of the vaccine for those who have received it; and 4) sharing easily understood, poignant stories of local community members experiencing long-COVID symptoms, which may illicit an emotional connection.

\section{Conclusion}

An analysis of COVID-19 vaccine discourse on SM identified four themes related to the perceptions, attitudes, beliefs, and intentions toward taking a COVID-19 vaccine. These included both negative (concerns about COVID-19 vaccine necessity, safety and efficacy) and positive (trust in COVID-19 vaccines as a safe solution) themes. Based on these findings, specific recommendations to reduce vaccine hesitancy were developed. 


\section{Authors' statement}

LT - Led the project, conceptualization and study design, methodology, data collection, formal analysis, and interpretation of data, writing, editing, and creating final draft SD - Conceptualization and study design, methodology, data collection, formal analysis, and interpretation of data, writing, editing, and creating final draft

$\mathrm{AL}$ - Methodology, formal analysis and interpretation of data, writing, editing, and creating final draft

All authors have reviewed and approved the final article.

The content and view expressed in this article are those of the authors and do not necessarily reflect those of the Government of Canada.

\section{Competing interests}

The authors declare no conflict of interest.

\section{Funding}

L Tang is supported in part by funding from the Social Sciences and Humanities Research Council.

\section{References}

1. World Health Organization. Naming the coronavirus disease (COVID-19) and the virus that causes it. Geneva, Switzerland: WHO; 2020 (accessed 2021-01-18). https://www.who.int/ emergencies/diseases/novel-coronavirus-2019/technicalguidance/naming-the-coronavirus-disease-(covid-2019)-andthe-virus-that-causes-it

2. Vogel L, Eggertson L. COVID-19: A timeline of Canada's first-wave response. CMAJ; 2020 (accessed 2021-08-26). https://cmajnews.com/2020/06/12/coronavirus-1095847/

3. World Health Organization. WHO Coronavirus (COVID-19) Dashboard. Geneva, Switzerland: WHO; 2021 (accessed 2021-01-18). https://covid19.who.int/

4. Health Canada. COVID-19 daily epidemiology update. Ottawa (ON): HC; 2021. https://health-infobase.canada.ca/ covid-19/epidemiological-summary-covid-19-cases.html

5. Andre FE, Booy R, Bock HL, Clemens J, Datta SK, John TJ, Lee BW, Lolekha S, Peltola H, Ruff TA, Santosham M, Schmitt HJ. Vaccination greatly reduces disease, disability, death and inequity worldwide. Bull World Health Organ 2008;86(2):140-6. DOI PubMed

6. Frederiksen LSF, Zhang Y, Foged C, Thakur A. The Long Road Toward COVID-19 Herd Immunity: Vaccine Platform Technologies and Mass Immunization Strategies. Front Immunol 2020;11:1817. DOl PubMed

7. Koirala A, Joo YJ, Khatami A, Chiu C, Britton PN. Vaccines for COVID-19: the current state of play. Paediatr Respir Rev 2020;35:43-9. DOI PubMed
8. Ministry of Health (Ontario). COVID-19 Vaccine Approval Process and Safety. Version 3.0 - March 11, 2021. Toronto, ON: MHLTC; 2021. https://www.health.gov.on.ca/en/pro/ programs/publichealth/coronavirus/docs/vaccine/COVID-19_ vaccine_approval_process_safety.pdf

9. Health Canada. Approved COVID-19 Vaccines. Ottawa (ON): HC; 2021 (accessed 2021-08- 28). https://www.canada.ca/ en/health-canada/services/drugs-health-products/covid19industry/drugs-vaccines-treatments/vaccines.html

10. Lin C, Tu P, Beitsch LM. Confidence and Receptivity for COVID-19 Vaccines: A Rapid Systematic Review. Vaccines (Basel) 2020;9(1):16. DOI PubMed

11. McGregor S, Goldman RD. Determinants of parental vaccine hesitancy. Can Fam Physician 2021;67(5):339-41. DOI PubMed

12. Vallis M, Glazer S. Protecting individuals living with overweight and obesity: attitudes and concerns toward COVID-19 vaccination in Canada. Obesity (Silver Spring) 2021;29(7):1128-37. DOI PubMed

13. World Health Organization. Top ten threats to global health in 2019. Geneva, Switzerland: WHO; 2019 (accessed 2021-01-18). https://www.who.int/news-room/spotlight/tenthreats-to-global-health-in-2019

14. MacDonald NE; SAGE Working Group on Vaccine Hesitancy. Vaccine hesitancy: Definition, scope and determinants. Vaccine 2015;33(34):4161-4. DOI PubMed

15. Dredze M, Broniatowski DA, Hilyard KM. Zika vaccine misconceptions: A social media analysis. Vaccine 2016;34(30):3441-2. DOI PubMed

16. Puri N, Coomes EA, Haghbayan H, Gunaratne K. Social media and vaccine hesitancy: new updates for the era of COVID-19 and globalized infectious diseases. Hum Vaccin Immunother 2020;16(11):2586-93. DOI PubMed

17. Ahmed N, Quinn SC, Hancock GR, Freimuth VS, Jamison A. Social media use and influenza vaccine uptake among White and African American adults. Vaccine 2018;36(49):7556-61. DOI PubMed

18. Statistics Canada. Majority of Canadians intend to get the COVID-19 vaccine, September 2020. Ottawa, ON: StatCan; 2020 (accessed 2021-01-18). https://www150.statcan.gc.ca/ n1/daily-quotidien/201217/dq201217c-eng.htm

19. Angus Reid Institute. More Canadians willing to roll up their sleeves right away as national COVID-19 vaccine rollout begins. Angus Reid; 2020. https://angusreid.org/canadacovid-vaccine-december/

20. World Health Organization. Coronavirus disease (COVID-19): Herd immunity, lockdowns and COVID-19. Geneva, Switzerland: WHO; 2020 (accessed 2021-08-28). https:// www.who.int/emergencies/diseases/novel-coronavirus-2019/ question-and-answers-hub/q-a-detail/herd-immunitylockdowns-and-covid-19 
21. Bond L, Nolan T. Making sense of perceptions of risk of diseases and vaccinations: a qualitative study combining models of health beliefs, decision-making and risk perception. BMC Public Health 2011;11(1):943-56. DOI PubMed

22. Mercadante AR, Law AV. Will they, or Won't they? Examining patients' vaccine intention for flu and COVID-19 using the Health Belief Model. Res Social Adm Pharm 2021;17(9):1596-605. DOl PubMed

23. Neubaum G, Krämer NC. Monitoring the Opinion of the Crowd: Psychological Mechanisms Underlying Public Opinion Perceptions on Social Media. Media Psychol 2017;20(3):502-31. DOI

24. Chun JW, Lee MJ. When does individuals' willingness to speak out increase on social media? Perceived social support and perceived power/control. Comput Human Behav 2017;74:120-9. DOI

25. Wu TY, Atkin DJ. To comment or not to comment: examining the influences of anonymity and social support on one's willingness to express in online news discussions. New Media Soc 2018;20(12):4512-32. DOI

26. Henrich N, Holmes B. What the public was saying about the $\mathrm{H} 1 \mathrm{~N} 1$ vaccine: perceptions and issues discussed in on-line comments during the $2009 \mathrm{H} 1 \mathrm{~N} 1$ pandemic. PLoS One 2011;6(4):e18479. DOl PubMed

27. Saleh SN, Lehmann CU, McDonald SA, Basit MA Medford RJ. Understanding public perception of coronavirus disease 2019 (COVID-19) social distancing on Twitter. Infect Control Hosp Epidemiol 2021;42(2):131-8. DOI PubMed

28. Kirzinger A, Kearney A, Hamel L, Brodie M. KFF health tracking poll-early April 2020: The impact of coronavirus on life in America. Kaiser Family Foundation; 2020 (accessed 2021-08-26). https://www.kff.org/coronavirus-covid-19/ report/kff-health-tracking-poll-early-april-2020/

29. Epstein K. Just $14 \%$ of Americans support ending social distancing in order to reopen the economy, according to a new poll. Business Insider; 2020. https://www. businessinsider.com/poll-most-americans-supportcoronavirus-social-distancing-measures-2020-4

30. Williams L, Gallant AJ, Rasmussen $S$, Brown Nicholls LA, Cogan N, Deakin K, Young D, Flowers P. Towards intervention development to increase the uptake of COVID-19 vaccination among those at high risk: outlining evidence-based and theoretically informed future intervention content. Br J Health Psychol 2020;25(4):1039-54. DOl PubMed

31. Riad $A$, Abdulqader $H$, Morgado $M$, Domnori $S$, Koščík M, Mendes JJ, Klugar M, Kateeb E, IADS-Score. Global Prevalence and Drivers of Dental Students' COVID-19 Vaccine Hesitancy. Vaccines (Basel) 2021;9(6):566. DOI PubMed

32. Coe AB, Elliott MH, Gatewood SB, Goode JV, Moczygemba LR. Perceptions and predictors of intention to receive the COVID-19 vaccine. Res Social Admin Pharm 2021;s1551-7411(21):000164-09. DOl PubMed
33. Griffith J, Marani H, Monkman H. COVID-19 Vaccine Hesitancy in Canada: Content Analysis of Tweets Using the Theoretical Domains Framework. J Med Internet Res 2021;23(4):e26874-e. DOI

34. Zhang S, Pian W, Ma F, Ni Z, Liu Y. Characterizing the COVID-19 Infodemic on Chinese Social Media: exploratory Study. JMIR Public Health Surveill 2021;7(2):e26090. DOI PubMed

35. Bonnevie E, Gallegos-Jeffrey A, Goldbarg J, Byrd B, Smyser J. Quantifying the rise of vaccine opposition on Twitter during the COVID-19 pandemic. J Commun Healthc 2021;14(1):12-9. DOI

36. Guntuku SC, Buttenheim AM, Sherman G, Merchant RM. Twitter discourse reveals geographical and temporal variation in concerns about COVID-19 vaccines in the United States. Vaccine 2021;39(30):4034-8. DOl PubMed

37. Dubé E, Gagnon D, MacDonald N, Bocquier A, Peretti-Watel P, Verger P. Underlying factors impacting vaccine hesitancy in high income countries: a review of qualitative studies. Expert Rev Vaccines 2018;17(11):989-1004. DOl PubMed

38. Ahmed W, Vidal-Alaball J, Downing J, López Seguí F. COVID-19 and the 5G Conspiracy Theory: Social Network Analysis of Twitter Data. J Med Internet Res 2020;22(5):e19458. DOI PubMed

39. Kim H, Han JY, Seo Y. Effects of Facebook Comments on Attitude Toward Vaccines: The Roles of Perceived Distributions of Public Opinion and Perceived Vaccine Efficacy. J Health Commun 2020;25(2):159-69. DOI PubMed

40. Clarke V, Braun V. Thematic analysis. J Posit Psychol 2017;12(3):297-8. DOI

41. Bowen GA. Grounded Theory and Sensitizing Concepts. Int J Qual Methods 2006;5(3):12-23. DOI

42. Sweileh WM. Bibliometric analysis of global scientific literature on vaccine hesitancy in peer-reviewed journals (1990-2019). BMC Public Health 2020;20(1):1252. DOl PubMed

43. Yaqub O, Castle-Clarke S, Sevdalis N, Chataway J. Attitudes to vaccination: a critical review. Soc Sci Med 2014;112:1-11. DOl PubMed

44. Carlsen B, Glenton C. The swine flu vaccine, public attitudes, and researcher interpretations: a systematic review of qualitative research. BMC Health Serv Res 2016;16:203. DOI PubMed

45. Karlsson LC, Soveri A, Lewandowsky S, Karlsson L, Karlsson H, Nolvi S, Karukivi M, Lindfelt M, Antfolk J. Fearing the disease or the vaccine: the case of COVID-19. Pers Individ Dif 2021;172:110590. DOI PubMed

46. Björkman I, Sanner MA. The Swedish $A(H 1 N 1)$ vaccination campaign--why did not all Swedes take the vaccination? Health Policy 2013;109(1):63-70. DOI PubMed 
47. Kim H-Y, Bershteyn A, McGillen JB, Braithwaite RS. Under what circumstances could vaccination offset the harm from a more transmissible variant of SARS-COV-2 in NYC? Trade-offs regarding prioritization and speed of vaccination. medRxiv. 2021:2021.01.29.21250710. DOI

48. Jennings W, Stoker G, Willis H, Valgardsson V, Gaskell J, Devine D, McKay L, Mills MC. Lack of trust and social media echo chambers predict COVID-19 vaccine hesitancy. medRxiv. 2021:2021.01.26.21250246. DOI

49. Driedger SM, Maier R, Furgal C, Jardine C. Factors influencing $\mathrm{H} 1 \mathrm{~N} 1$ vaccine behavior among Manitoba Metis in Canada: a qualitative study. BMC Public Health 2015;15(1):128. DOI PubMed

50. Kowal SP, Jardine CG, Bubela TM. "If they tell me to get it, I'll get it. If they don't...": immunization decision-making processes of immigrant mothers. Can J Public Health 2015;106(4):e230-5. DOl PubMed

51. Broniatowski DA, Jamison AM, Qi S, AlKulaib L, Chen T, Benton A, Quinn SC, Dredze M. Weaponized Health Communication: Twitter Bots and Russian Trolls Amplify the Vaccine Debate. Am J Public Health 2018;108(10):1378-84. DOI PubMed
52. Yuan X, Schuchard RJ, Crooks AT. Examining Emergent Communities and Social Bots Within the Polarized Online Vaccination Debate in Twitter. Soc Media Soc. 2019;5(3):2056305119865465. DOI

53. Archibald MM. Investigator Triangulation: A Collaborative Strategy With Potential for Mixed Methods Research. J Mixed Methods Res 2015;10(3):228-50. DOI

54. Hidiroglu S, Ay P, Topuzoglu A, Kalafat C, Karavus M. Resistance to vaccination: the attitudes and practices of primary healthcare workers confronting the H1N1 pandemic. Vaccine 2010;28(51):8120-4. DOI PubMed

55. Nowak GJ, Sheedy K, Bursey K, Smith TM, Basket $M$. Promoting influenza vaccination: insights from a qualitative meta-analysis of 14 years of influenza-related communications research by U.S. Centers for Disease Control and Prevention (CDC). Vaccine 2015;33(24):2741-56. DOl PubMed

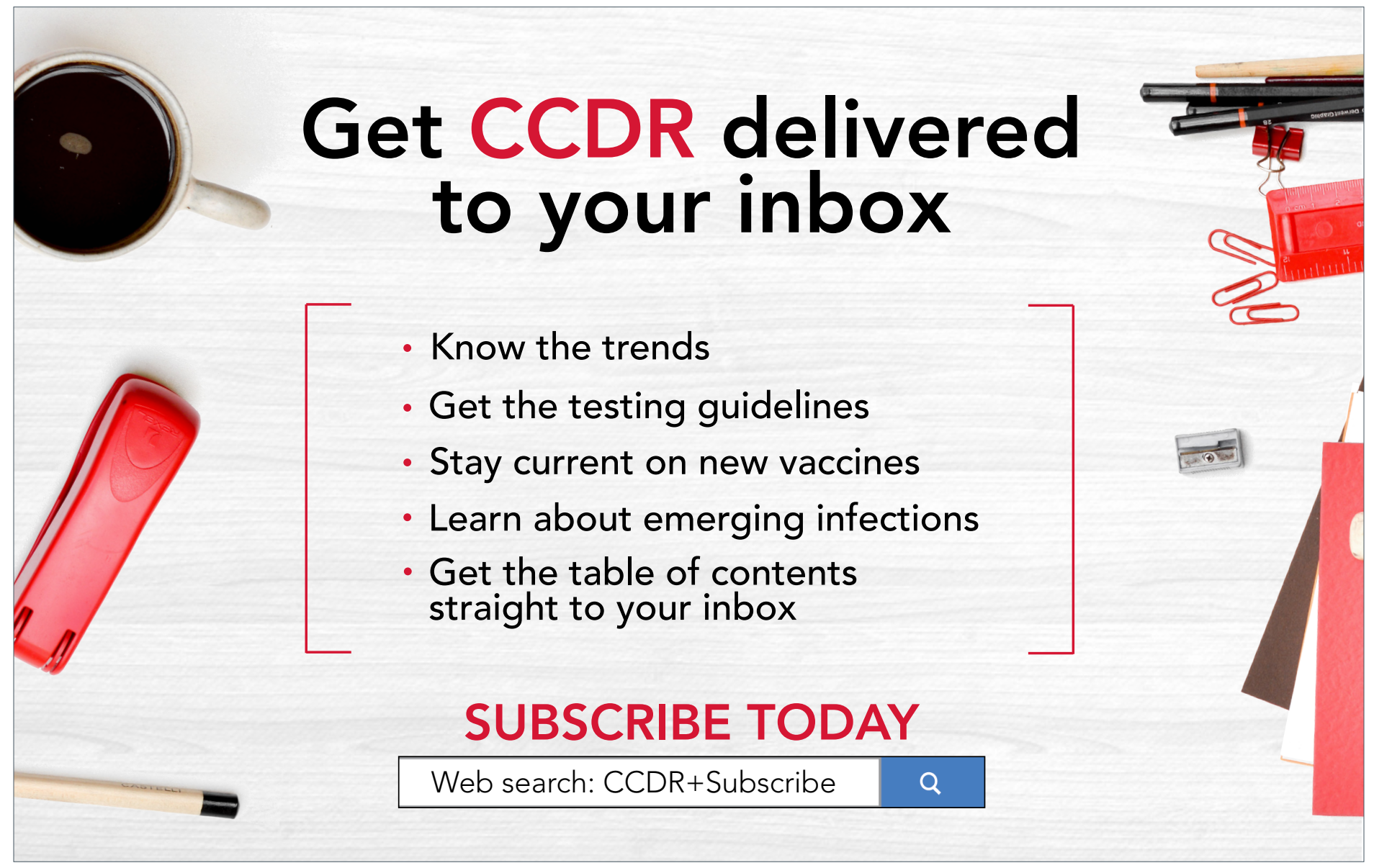

